\title{
Cereal Straw Mulching in Strawberry-A Facilitator of Plant Visits by Edaphic Predatory Mites at Night?
}

\author{
Fernanda de Cássia Neves Esteca ${ }^{1, * \mathbb{D}}$, Nina Trandem ${ }^{2,3}$, Ingeborg Klingen ${ }^{3}$, \\ Jandir Cruz Santos ${ }^{4}$, Italo Delalibera Júnior ${ }^{1}{ }^{10}$ and Gilberto José de Moraes ${ }^{1}$ \\ 1 Department of Entomology and Acarology, “Luiz de Queiroz” College of Agriculture (ESALQ), \\ University of São Paulo (USP), Av. Pádua Dias, 11, Piracicaba SP 13418-900, Brazil; \\ delalibera@usp.br (I.D.J.); moraesg@usp.br (G.J.d.M.) \\ 2 Faculty of Environmental Sciences and Natural Resource Management, Norwegian University of Life \\ Sciences (NMBU), P.O. Box 5003, 1432 Ås, Norway; nina.trandem@nibio.no \\ 3 Biotechnology and Plant Health Division, Norwegian Institute of Bioeconomy Research (NIBIO), \\ P.O. Box 115, 1431 Ås, Norway; ingeborg.klingen@nibio.no \\ 4 Centre for Biodiversity Genomics, 50 Stone Road East, University of Guelph, Guelph, ON N1G2W1, Canada; \\ jandir_jc@hotmail.com \\ * Correspondence: fernanda.esteca@usp.br
}

Received: 3 May 2020; Accepted: 27 May 2020; Published: 13 June 2020

\begin{abstract}
In Norway, strawberry producers use cereal straw mulching to prevent berries from contacting the soil and to control weeds. We hypothesized that organic matter such as straw mulch also favors the maintenance of predatory mites which visit strawberry plants at nighttime. We compared mite diversity in cereal straw exposed for different periods in strawberry fields and evaluated their possible migration to plants in two experiments with potted plants in 2019. An 'Early season' experiment compared no mulching (T1), oat straw mulch exposed in field since 2018 (T2), or 2017 (T3), while a 'Mid-season' experiment compared no mulching (T1), barley straw mulch from 2018 (T2), or a mix from 2017 and 2018 (T3). To provide edaphic predatory mites with a potential source of food, all plants were infested with two-spotted spider mite (Tetranychus urticae Koch). Results suggested that straw mulch facilitates the prevalence of predatory mites in strawberry fields. Most predatory mite visits were at night, confirming our initial hypothesis. Predominant nocturnal mites on leaves belonged to Melicharidae (Proctolaelaps sp.) ('Early season', T2), Blattisociidae (Lasioseius sp.) ('Early and Mid-season', T3) and Phytoseiidae ('Mid-season', T2). Parasitus consanguineus Oudemans \& Voigts was the predominant species ('Early season', T3) at the base of plants. Anystidae were diurnal visitors only ('Mid-season', T2). Future studies should evaluate the predation potential of Proctolaelaps sp. and Lasioseius sp. on two-spotted spider mite and other strawberry pests.
\end{abstract}

Keywords: oat straw mulch; barley straw mulch; biological control; two-spotted spider mite; edaphic mites

\section{Introduction}

The use of mulching (a plastic film or an organic material) is an important technique in strawberry (Fragaria $\times$ ananassa Duch.) cultivation, to regulate soil temperature, suppress weeds, prevent erosion, and prevent berries from contact with the soil [1].

In Norwegian strawberry production, cereal straw is commonly used as a mulching material. In roughly half of the strawberry production area, cereal straw is the only mulching material, whilst in another $25 \%$, straw is combined with a black plastic film beneath it [2]. Strawberry is an important fruit crop in Norway, accounting for 70\% of the yield of soft fruit production in the country [3]. In 2019, 
about 9000 metric tons of strawberries were produced by Norwegian farmers, with revenue of about NOK 455 million (USD 45.5 million) [4]. Most of the strawberry production is done in open fields, where the plants are harvested for $2-3$ years. The most common pests in strawberry cultivation in Norway are: two phytophagous mites, the two-spotted spider mite, Tetranychus urticae Koch [5], and the strawberry tarsonemid mite, Phytonemus pallidus (Banks); two weevils, Anthonomus rubi Herbst and Otiorhynchus sulcatus F.; and a capsid bug, Lygus rugulipennis L. [6-8].

According to Kader et al. [9], there are many advantages of using organic material instead of plastic as mulching; for example, the former can improve soil structure throughout the degradation process, in addition to the more efficient balancing of soil temperature. Another advantage is the maintenance of higher densities of certain pest predators, such as beetles of the families Carabidae and Staphylinidae, and spiders of the families Linyphiidae and Lycosidae, providing them with a more suitable environment [10]. Further, Larentzaki et al. [11] reported reduction in thrips populations in onion crops whose soil was covered with oat straw.

Beneficial mites can also benefit from organic mulching. An increase in the abundance and diversity of Gamasina mites and/or a decrease in pest populations in different crops have been reported by several authors [12-15]. Gamasina is a cohort of the order Mesostigmata, which comprises a large group of mites found in different habitats, but especially in the soil. Although many of these can feed on fungi, they are well known as predators of small invertebrates, including mites, nematodes, and insects. For this reason, the members of this group have been studied as predators of edaphic pests [16].

Mites, as well as Collembola and some other Hexapoda, are part of the soil mesofauna (length $200 \mu \mathrm{m}-2 \mathrm{~mm}$ ), many of which fragmentize the organic matter available on the soil surface [17]. The macrofauna ( $>2 \mathrm{~mm}$ ), in particular earthworms, also participate in the process of organic matter fragmentation [18]. The soil microbiota, which includes the microfauna and other small organisms $(<100 \mu \mathrm{m})$, including bacteria, fungi and nematodes, is also a key element in the cycling of organic matter [19]. Thus, it is expected that throughout the process of decomposition of organic matter, such as straw mulch, the characteristics of the soil will vary, influencing the fauna of edaphic predatory mites.

Hence, soil with better coverage, naturally represented by dead plant structures on its surface or resulting from the purposeful introduction by growers, has a higher density of predatory mites, as extensively reported in the literature [20-23]. Consequently, in agricultural lands, the use of organic cover should benefit pest control by acting as a reservoir of edaphic predatory mites.

An aspect that has been little mentioned in the literature on predatory mites is the movement of soil mites from protected to exposed habitats, like plants, at night [24-26]. In Brazil, Esteca et al. [20] found that Proctolaelaps pygmaeus (Muller) (Melicharidae) and Blattisocius dentriticus (Berlese) (Blattisociidae) were present on strawberry leaflets mainly at night, indicating their possible daily migration from the edaphic environment to the plants. The reason for this behavior has not been properly studied. It could be casual or linked to the direct effect of light or other abiotic factors (such as temperature and humidity), or to biotic factors. Our previous experience has shown that representatives of edaphic Gamasina (Lasioseius floridensis Berlese (Blattisociidae), Cosmolaelaps sp. (Laelapidae), Proctolaelaps bickleyi (Bram) (Melicharidae), Protogamasellopsis posnaniensis Wisniewski \& Hirschmann (Rhodacaridae) and Stratiolaelaps scimitus (Womersley) (Laelapidae)) will perish in a few hours when subjected to relative humidity levels below $70 \%$. Due to the increase in air relative humidity at night, this period is probably the most suitable for predatory Gamasina mites to migrate temporarily onto plants in search of prey. The possible migration of L. floridensis from the soil to plants and vice versa was conceived by Britto et al. [27]. However, it is expected that the movement of edaphic Gamasina to plants varies from place to place, according to the faunistic composition and the intrinsic preference of the local mite fauna.

The hypotheses of the work we will present were: (a) Species richness and abundance of predatory mites (especially Gamasina) in organic material increases with the time the matter has been exposed 
on the soil surface in the strawberry field; and (b) mites present in the organic mulching at daytime climb to strawberry plants at nighttime in potting experiments in climatic chambers.

The objective of this study was therefore to compare the diversity and prevalence of mites in cereal straw subjected to different periods of exposure in the strawberry field, evaluating their possible temporary movement from the edaphic habitat to strawberry plant leaves at nighttime.

\section{Materials and Methods}

Two consecutive experiments, one 'Early season' and one 'Mid-season', were carried out during May-July 2019, in a climatic room at the Department of Biotechnology and Plant Health of Norwegian Institute of Bioeconomy Research (NIBIO), Ås, Norway. The room was maintained at $18 \pm 2{ }^{\circ} \mathrm{C}$, $70 \pm 5 \%$ relative humidity and a daily photoperiod of $15 \mathrm{~h}$, turning the lights on at 6:00 a.m. (500 $\mu \mathrm{mol}$ (quanta) $\mathrm{m}^{-2} \cdot \mathrm{s}^{-1}$ ) and off at 9:00 p.m. These parameters simulated the average light conditions of the region during the study period.

\subsection{Experimental Set-Up}

In both experiments, potted strawberry plants received one of three treatments (T): In $\mathrm{T} 1$ no mulch was added (control treatment), in T2 cereal straw mulch present in a strawberry crop since last autumn (standard practice) was added, and in T3 cereal straw one year older than in T2 was added. Each treatment had 13 replicates per experiment, and each experiment lasted 5 weeks.

\subsection{Preparing Experimental Pots and Plants}

Pots (5 L) were filled to $80 \%$ capacity with a commercial organic substrate (Kompostert Plantejord ${ }^{\circledR}$, Lillestrøm, Norway); composition: 50\% peat, 50\% garden waste, macro- and micronutrients). One strawberry plant of $\mathrm{cv}$ 'Korona', approximately $10 \mathrm{~cm}$ high and with about five trifoliate leaves, free of pests or diseases, was transplanted into each pot. Pots were placed $15 \mathrm{~cm}$ apart on four shelves in the climatic room. To avoid movement of mites from one pot to another, the upper edge of each pot was covered with entomological glue (Tangle trap, Biocontrol ${ }^{\circledR}$, Grossdietwil, Switzerland).

To provide edaphic predatory mites with a potential source of food, two adult females of the two-spotted spider mite were transferred to each of six random leaflets per plant two days after transplanting. Infested leaflets were marked with a pen ( $3 \mathrm{~mm}$ in diameter), so that they could be examined for mite presence along the experiment. One week after the transplant, plants were fertilized with $8 \mathrm{~g}$ of Plantagen ${ }^{\circledR}$ (Uddevalla, Sweden) fertilizer $(2 \mathrm{~N}$ : 3P: $1 \mathrm{~K})$ per pot. The plants were irrigated manually to field capacity (about $10 \mathrm{~mL}$ per pot) once every two days.

\subsection{Sampling Straw Mulch and Soil in the Field}

For both experiments, cereal straw mulch of two ages ( 1 and 2 two years old), but otherwise as similar as possible, was collected on a strawberry farm near NIBIO (details given in Table 1). A frame of $55 \times 25 \mathrm{~cm}$ was used to standardize sampling, each subsample taken in spots about $4 \mathrm{~m}$ apart, always next to bed margin, maximum $15 \mathrm{~cm}$ from a strawberry plant. Subsamples of ca. $2 \mathrm{~L}$ were collected and pooled into $40 \mathrm{~L}$ plastic bags and taken to the laboratory. The straw used in the strawberry field originated from cereal production at the same farm as the strawberry field, where no insecticides were used.

Soil samples from the same fields were also collected by the use of a standard probe $(6 \mathrm{~cm}$ deep, $10 \mathrm{~cm}$ in diameter), transferring each sample to a plastic bag that was brought to the laboratory.

At the time of the 'Early season' sampling, the strawberry plants in the two fields were approximately $30 \mathrm{~cm}$ high and had about 15 leaves each (grade 55 according to BBCH-scale-phenological strawberry developmental stage [28]). They had been covered with Agryl fleece a few weeks before, to avoid frost damage to flowers, a common practice in the region. The fleece was removed to sample straw and soil. The cultivation practices of both fields were approximately the same, belonging to the same grower, and no pesticides had been used that growing season. 
At the 'Mid-season' sampling, plants in the sampled field were approximately $30 \mathrm{~cm}$ high and had about 30 leaves each; with no flowers open BBCH-scale 57 [28]. The straw and soil collection process in the field was the same as in the 'Early season'. They had been covered with Agryl fleece a few weeks before, to avoid frost damage to flowers, a common practice in the region. The fleece was removed to sample straw and soil.

Table 1. Details of the different types of straw used in the study and the fields from which they were collected. All fields belonged to the same grower (County of Viken) in SE Norway. $\mathrm{RH}=$ Relative humidity.

\begin{tabular}{|c|c|c|c|c|c|}
\hline $\begin{array}{c}\text { Experiment } \\
\text { Treatment }(\mathrm{T}) \text { * }\end{array}$ & Date Collected & $\begin{array}{c}\text { Temperature, RH, } \\
\text { Precipitation ** }\end{array}$ & Location & Type of Straw & $\begin{array}{l}\text { Length of Exposure } \\
\text { in the Field }\end{array}$ \\
\hline $\begin{array}{c}\text { 'Early season' } \\
\text { T2 }\end{array}$ & May 6, 2019 & $\begin{array}{c}3.3-4.0^{\circ} \mathrm{C} ; \\
77-82 \% \mathrm{RH} \\
6 \mathrm{~mm}\end{array}$ & $\begin{array}{l}59^{\circ} 39^{\prime} 38^{\prime \prime} \mathrm{N} ; 10^{\circ} 40^{\prime} 37^{\prime \prime} \mathrm{E} \\
\text { Altitude } 90 \text { masl, Loam soil }\end{array}$ & Oat & Since autumn 2018 \\
\hline $\begin{array}{l}\text { 'Early season' } \\
\text { T3 }\end{array}$ & May 6, 2019 & $\begin{array}{c}3.3-4.0^{\circ} \mathrm{C} ; \\
77-82 \% \mathrm{RH} ; \\
6 \mathrm{~mm}\end{array}$ & $\begin{array}{l}59^{\circ} 39^{\prime} 30^{\prime \prime} \mathrm{N} ; 10^{\circ} 41^{\prime} 13^{\prime \prime} \mathrm{E} \\
\text { Altitude } 100 \text { masl, Silty loam soil }\end{array}$ & Oat & Since autumn 2017 \\
\hline 'Mid-season' T2 & June 23, 2019 & $\begin{array}{l}11.4-13.0^{\circ} \mathrm{C} ; \\
75-83 \% \mathrm{RH} ; \\
29 \mathrm{~mm}\end{array}$ & $\begin{array}{l}59^{\circ} 39^{\prime} 51^{\prime \prime} \mathrm{N} ; 10^{\circ} 41^{\prime} 4^{\prime \prime} \mathrm{E} \\
\text { Altitude } 100 \text { masl, Silty loam soil }\end{array}$ & Barley & Since autumn 2018 \\
\hline 'Mid-season' T3 & June 23, 2019 & $\begin{array}{l}11.4-13.0^{\circ} \mathrm{C} ; \\
75-83 \% \mathrm{RH} ; \\
29 \mathrm{~mm}\end{array}$ & $\begin{array}{l}59^{\circ} 39^{\prime} 51^{\prime \prime} \mathrm{N} ; 10^{\circ} 41^{\prime} 4^{\prime \prime} \mathrm{E} \\
\text { Altitude } 100 \text { masl, Silty loam soil }\end{array}$ & Barley & $\begin{array}{l}\text { Mixture of autumn } \\
2017 \text { (lower layer) and } \\
2018 \text { (upper layer) }\end{array}$ \\
\hline
\end{tabular}

\subsection{Berlese Funnel Extraction of Mites}

To get data on prevalence of predatory mites in the different straw treatments at the time of collection, straw samples were processed in the laboratory by placing a part of the samples (not the same as that used as mulching in the pots in the experiment of the climatic room) in modified Berlese funnels [29] at the beginning of each experiment. For each straw treatment, 13 Berlese funnels were employed. The corresponding soil sampled in the strawberry fields was also placed to Berlese funnels (13 samples) to evaluate the prevalence of predatory mites. The volume of sample in each Berlese funnel was $1 \mathrm{~L}$. Mites dropping from each funnel were caught in a container with $70 \%$ ethanol. The extraction process lasted 7 days.

The commercial potting organic substrate used in experimental pots was investigated in the same way to reveal whether it contained mites that would affect the study.

At the end of each experiment, similar Berlese extractions were performed with the material from experimental pots (straw or potting substrate): For T1 (potting substrate only), a sample (1 L per pot) of the upper part of the potting substrate was taken from each pot. For T2 and T3, all the straw (1 L) covering the substrate of each pot was analyzed.

The material from each Berlese funnel extraction was screened in a stereomicroscope, and all mites were mounted in Hoyer's medium for identification. The identifications to family were carried out using taxonomic keys provided by Krantz and Walter [30], to genera by using unpublished keys provided by the Ohio Summer Program, Agricultural Acarology, Columbus, Ohio, USA, and to species by using published descriptions and redescriptions of the species of each family.

\subsection{Observation and Sampling of Mites on Marked Leaflets during Experiments}

Once a week for four consecutive weeks, the number of mites was counted on the six leaflets of each plant previously infested with two-spotted spider mite. Each mite was categorized as Mesostigmata, Prostigmata, or Oribatida. At each date, evaluations were carried out at 3, 7, and 11 a.m., and 3, 7, and 11 p.m. Evaluations were conducted with a hand-held lens $(40 \times)$ on both leaflet surfaces. During the dark phase ( 3 a.m. and 11 p.m.), evaluations were conducted by the use of a hand-held lens $(40 \times)$ illuminated with a headlight. All non-two-spotted spider mites found on the first evaluated leaflet of each plant in all second and fourth weekly evaluations were collected and mounted on slides 
using Hoyer's medium for later identification. The identifications were performed as described in the previous paragraph.

\subsection{Extraction of Mites from the Whole Plant (End of Experiments)}

Each experiment was ended after 5 weeks by a destructive sampling in which 6 of the plants of each treatment were cut at the plant base at 11 a.m., and the remaining 7 plants were cut at 11 p.m. Each plant was divided into three parts: (a) basal region (first two centimeters from the plant base); (b) young leaves, still folded; and (c) remainder of the plant (mature leaves and petioles). Each part was immediately placed in a plastic bag containing $70 \%$ ethanol and shaken vigorously. The liquid was subsequently poured through a $160 \mu \mathrm{m}$ sieve. To extricate any remaining mites, the plant material was further rinsed using jets of 70\% ethanol. The mites retained in the sieve were mounted for identification and quantification under a stereomicroscope (100x).

To investigate the possible occurrence of the fungus Neozygites floridana (Weiser \& Muma) Remaudière \& Keller (Entomophthorales: Neozygitaceae), a pathogen of the two-spotted spider mite, a sample of two-spotted spider mite was mounted in Hoyer's medium (maximum 10 mites/plant part/plant) for examination under the stereomicroscope (100×).

\subsection{Statistical Analysis}

Numbers of Mesostigmata and two-spotted spider mite in the different treatments were analyzed statistically as follows: For Mesostigmata, the means were contrasted (just between T2 and T3 in both experiments, given that Mesostigmata were not found in T1) by the F test, from the generalized linear model of the quasi-Poisson distribution (Anova, model.QuasiPoisson, test $=$ "F"), in R [31]. For the two-spotted spider mites, the untransformed data were fitted to a quasi-Poisson distribution. Means were compared using the glht multicomp package, in R [31]. The predominant species of Mesostigmata were calculated as proposed by Pinzón and Spence [32].

\section{Results}

\subsection{Mites Extracted from Commercial Potting Substrate, Soil and Mulching Straw}

No mites were found in the commercial potting substrate, neither at the start nor at the end of the experiments. This strongly indicates that all mites eventually found on the strawberry plants of T2 and T3 originated from the straw used as mulch. Regarding the soil samples, the average number of mites per sample of the 'Early season' were low in both T2 and T3 (1.2 \pm 0.4 and $1.7 \pm 0.5$ mites, respectively), none of them Gamasina. In the 'Mid-season', averages were also low $(0.5 \pm 0.2$ and $0.7 \pm 0.3$ mites, respectively), and the only Gamasina found were Amblygamasus sp. and Pergamasus longicornis (Berlese) (both Parasitidae) and Rhodacarellus epigynalis Shels (Rhodacaridae).

In contrast, the total numbers of mites in straw samples to be used in T2 and T3 in the 'Early season', were relatively high, with the proportion of Gamasina higher in T3 than in T2 $(18 \%$ and $6.0 \%$, respectively) (Table 2). Consequently, the mean number of Gamasina per sample was significantly higher in T3 $(7.8 \pm 0.6)$ than in T2 (3.5 \pm 0.7$)(\mathrm{Df}=1 ; \mathrm{F}=16.5 ; p<0.001)$. In the 'Mid-season', the total numbers of mites in T2 and T3 were lower at the start, of which $15.8 \%$ and $38.6 \%$ were Gamasina. As in the 'Early season', the mean number of Gamasina per sample was higher in the straw of T3 $(11.9 \pm 1.9)$ than of $\mathrm{T} 2(2.7 \pm 0.7)(\mathrm{Df}=1 ; \mathrm{F}=26.9 ; p<0.001)$. 
Table 2. Mites extracted in Berlese funnels from samples of four types of cereal straw mulching used in two climate chamber experiments in 2019. The mulching had been present in strawberry fields for different periods of time, as indicated in column headings. B = Samples taken at the start of experiment; $\mathrm{E}=$ taken at the end of the experiment. $n=13$ samples of $1 \mathrm{~L}$ per straw type and sampling occasion.

\begin{tabular}{|c|c|c|c|c|c|c|c|c|}
\hline \multirow{3}{*}{$\begin{array}{l}\text { Experiments } \\
\text { Treatments } \\
\text { Taxa/Collection }\end{array}$} & \multicolumn{4}{|c|}{ ‘Early Season' Experiment } & \multicolumn{4}{|c|}{ ‘Mid-Season' Experiment } \\
\hline & \multicolumn{2}{|c|}{ T2 (Oat Straw 2018) } & \multicolumn{2}{|c|}{ T3 (Oat Straw 2017) } & \multicolumn{2}{|c|}{ T2 (Barley Straw 2018) } & \multicolumn{2}{|c|}{ T3 (Barley Straw 2017-2018) } \\
\hline & B & E & B & E & B & $\mathbf{E}$ & B & E \\
\hline \multicolumn{9}{|l|}{ Sarcoptiformes, Oribatida, Astigmatina } \\
\hline \multicolumn{9}{|l|}{ Acaridae } \\
\hline Tyrophagus putrescentiae & 48 & 92 & 130 & 35 & 17 & 22 & 15 & 7 \\
\hline Winterschimidtiidae & 0 & 0 & 8 & 0 & 0 & 0 & 0 & 0 \\
\hline \multicolumn{9}{|l|}{ Sarcoptiformes, other Oribatida } \\
\hline- & 119 & 11 & 109 & 7 & 23 & 5 & 149 & 16 \\
\hline \multicolumn{9}{|l|}{ Trombidiformes, Prostigmata } \\
\hline \multicolumn{9}{|l|}{ Anystidae } \\
\hline Anystis sp. & 0 & 0 & 0 & 0 & 32 & 27 & 2 & 0 \\
\hline \multicolumn{9}{|l|}{ Cunaxidae } \\
\hline Cunaxoides croceus & 0 & 0 & 3 & 0 & 0 & 0 & 0 & 0 \\
\hline \multicolumn{9}{|l|}{ Ereynetidae } \\
\hline \multirow{2}{*}{\multicolumn{9}{|c|}{ Eupodidae }} \\
\hline & & & & & & & & \\
\hline Eupodes spp. & 239 & 0 & 46 & 0 & 64 & 50 & 31 & 66 \\
\hline Pygmephoridae & & & & & & & & \\
\hline Siteroptes sp. & 1 & 0 & 2 & 0 & 0 & 0 & 1 & 0 \\
\hline Tydeidae & & & & & & & & \\
\hline Lorryia oregonensis & 167 & 6 & 129 & 46 & 22 & 20 & 33 & 21 \\
\hline Parasitiformes, Mesostigmata, Gam & & & & & & & & \\
\hline Ascidae & & & & & & & & \\
\hline Gamasellodes bicolor & 0 & 0 & 1 & 0 & 0 & 0 & 0 & 0 \\
\hline Neojordensia sinuata o & 1 & 0 & 0 & 0 & 0 & 0 & 0 & 0 \\
\hline Blattisociidae & & & & & & & & \\
\hline Lasioseius sp. & 14 & 12 & 3 & 1 & 5 & $15 *$ & 1 & $14 *$ \\
\hline Eviphididae & & & & & & & & \\
\hline Alliphis halleri & $9 *$ & 5 & 5 & 0 & 0 & 0 & 7 & 3 \\
\hline Alliphis sp. immature & 1 & 0 & 0 & 0 & 0 & 0 & 0 & 0 \\
\hline Melicharidae & & & & & & & & \\
\hline Proctolaelaps sp. & $14 *$ & $102 *$ & 0 & 0 & 0 & 0 & 0 & 0 \\
\hline Parasitidae & & & & & & & & \\
\hline Amblygamasus sp. & 0 & 0 & 0 & 0 & 4 & 3 & 20 & 0 \\
\hline Amblygamasus sp. (immature) & 0 & 0 & 0 & 0 & 0 & 1 & 16 & 0 \\
\hline Parasitus consanguineus & 0 & 0 & 1 & 7 & 0 & 0 & 0 & 0 \\
\hline Parasitus sp. (deutonymph) & 1 & 0 & 7 & 0 & 0 & 0 & 0 & 0 \\
\hline Pergamasus longicornis & 0 & 0 & 3 & 2 & $14 *$ & 4 & $42 *$ & 2 \\
\hline Pergamasus septentrionalis & 0 & 0 & 10 & 0 & 0 & 0 & 5 & 2 \\
\hline Pergamasus sp. (deutonymph) & 0 & 0 & $26^{*}$ & 2 & 1 & 4 & 17 & 0 \\
\hline Pergamasus sp. $\sigma^{\pi}$ & 0 & 0 & 0 & 2 & 0 & 0 & 0 & 0 \\
\hline Porrhostaspis lunulata & 0 & 0 & 0 & 0 & 0 & 8 & 4 & $7 *$ \\
\hline Porrhostaspis sp. (deutonymph) & 0 & 0 & 1 & 2 & 0 & 0 & 1 & 0 \\
\hline Immature & 1 & 0 & 2 & 1 & 2 & 1 & 3 & 0 \\
\hline Phytoseiidae & & & & & & & & \\
\hline Neoseiulus alpinus & 1 & 2 & 3 & 1 & 0 & 0 & 0 & 0 \\
\hline Neoseiulus cucumeris & 0 & 0 & 0 & 0 & 2 & 2 & 0 & 1 \\
\hline Neoseiulus sp. immature & 0 & 1 & 3 & 1 & 0 & 0 & 0 & 0 \\
\hline Proprioseiopsis okanagensis & 0 & 0 & 3 & 0 & 1 & 2 & 0 & 0 \\
\hline Typhlodromips masseei & 1 & 0 & 13 & 0 & 0 & 0 & 5 & 2 \\
\hline Immature & 0 & 0 & 17 & 0 & 0 & 0 & 0 & 0 \\
\hline Rhodacaridae & & & & & & & & \\
\hline Rhodacarellus epigynalis & 0 & 0 & 0 & 0 & 1 & 0 & 2 & 3 \\
\hline Rhodacarellus kreuzi & 0 & 0 & 1 & 0 & 0 & 0 & 0 & 0 \\
\hline Rhodacarellus sp. immature & 1 & 0 & 0 & 0 & 0 & 0 & 0 & 0 \\
\hline Veigaiidae & & & & & & & & \\
\hline Veigaia nemorensis & 1 & 0 & 0 & 0 & 0 & 0 & $22 *$ & 2 \\
\hline Veigaia sp. immature & 0 & 0 & 2 & 0 & 0 & 0 & 0 & 0 \\
\hline Total & 754 & 231 & 545 & 105 & 189 & 166 & 376 & 152 \\
\hline
\end{tabular}

$\left({ }^{*}\right)$ Predominant Gamasina species; (-) Not identified family.

The predominant gamasine families in 'Early season' T2 were Blattisociidae (33.3\%), Melicharidae $(31.1 \%)$ and Eviphididae (22.2\%), each of the others representing a maximum of $4.4 \%$ of the total Gamasina. In T3, the predominant gamasine families were Parasitidae (49.5\%) and Phytoseiidae $(38.6 \%)$, each of the others representing a maximum of $4.9 \%$. At the species level in the 'Early season', the predominant ones were Alliphis halleri (G. \& R. Canestrini) (Eviphididae) and Proctolaelaps sp. (Melicharidae) in T2, and Pergamasus sp. (Parasitidae) in T3. In the 'Mid-season', the predominant family was Parasitidae in both treatments with straw (T2 $=76.1 \%$ and $\mathrm{T} 3=71.4 \%$ ), other families representing a maximum of $4.5 \%$ and $14.3 \%$, respectively. At the species level in this experiment, P. longicornis 
(Parasitidae) and Lasioseius sp. (Blattisociidae) were predominant in T2 and T3, and Veigaia nemorensis (Koch) (Veigaiidae), in T3.

At the end of the 'Early season', the total numbers of mites found in the straw of T2 and T3 were 231 and 105, respectively, Gamasina representing $52.8 \%$ and $16.1 \%$ of these (Table 2). Consequently, the mean number of Gamasina per sample was significantly higher in T2 than in T3 $(9.4 \pm 1.3$ and $1.3 \pm 0.4$, respectively) ( $\mathrm{Df}=1 ; \mathrm{F}=47.7 ; p<0.001)$. At the end of the 'Mid-season', the total numbers of mites in T2 and T3 were similar (166 and 152, respectively), and the proportions of Gamasina were also similar, $24.1 \%$ and $23.6 \%$ respectively (Table 2), resulting in no statistical difference between their mean numbers per sample ( $3.1 \pm 0.7$ and $2.8 \pm 0.7$, respectively) $(\mathrm{Df}=1 ; \mathrm{F}=0.1 ; p=0.75)$.

At the end of experiments, the predominant gamasine families in 'Early season' were Melicharidae (83.6\%) and Blattisociidae (9.8\%) in T2, each of the other families representing a maximum of $4.1 \%$ of the total Gamasina. In T3, the predominant gamasine families were Parasitidae $(84.2 \%)$ and Phytoseiidae (10.5\%), each of the others representing 5.2\%. In this experiment, the predominant species were Proctolaelaps sp. (Melicharidae) in T2, and Pergamasus sp. (Parasitidae) in T3. In the 'Mid-season', the predominant families in both treatments were Parasitidae (T2 $=52.5 \%$; T3 $=30.5 \%$ ) and Blattisociidae ( $\mathrm{T} 2=37.5 \%$; $\mathrm{T} 3=38.9 \%$ ), other families representing a maximum of $10 \%$ and $8.3 \%$, respectively. In this experiment, Lasioseius sp. (Blattisociidae) was the predominant species at the end of both T2 and T3 and Porrhostaspis lunulata Müller (Parasitidae), in T2.

\subsection{Mites on Marked Leaflets}

Two-spotted spider mite was the only mite species found on the T1 marked leaflets of both experiments, which was expected, given that no mites were observed in the commercial substrate used for all treatments and that this was the only material present in the pots of T1 (Table 3). On the other hand, the totals of Gamasina observed on T2 and T3 leaflets were low throughout both experiments, with a maximum of four mites in T2 (in the third week of evaluation of the 'Early season') and of five mites in T3 (in the fourth week of evaluation of the 'Mid-season'). This makes it difficult to compare treatments statistically. Nevertheless, gamasine mites could be seen moving on the straw surface at night.

Table 3. Total mites (except Tetranychus urticae) collected in the second and fourth evaluations at 3 , 7, 11 a.m. and 3, 7, 11 p.m. on the six marked leaflets with T. urticae/plant ( $n=13$ plants/treatment) in two lab experiments for different periods of time: 'Early season' experiment (oat straw: T2, since 2018; T3, since 2017); 'Mid-season' experiment (barley straw: T2, since 2018; T3, lower half layer since 2017 and top half layer since 2018). Light was on from 6 a.m. to 9 p.m.

\begin{tabular}{|c|c|c|c|c|}
\hline \multirow{2}{*}{$\begin{array}{l}\text { Experiments } \\
\text { Taxa/Treatments }\end{array}$} & \multicolumn{2}{|c|}{ 'Early Season' Experiment } & \multicolumn{2}{|c|}{ ‘Mid-Season' Experiment } \\
\hline & T2 (Oat Straw 2018) & T3 (Oat Straw 2017) & T2 (Barley Straw 2018) & T3 (Barley Straw 2017-2018) \\
\hline \multicolumn{5}{|l|}{ Trombidiformes, Prostigmata } \\
\hline \multicolumn{5}{|l|}{ Anystidae } \\
\hline Anystis sp. & 0 & 0 & 22 & 0 \\
\hline \multicolumn{5}{|c|}{ Parasitiformes, Mesostigmata, Gamasina } \\
\hline \multicolumn{5}{|c|}{ Ascidae } \\
\hline Neojordensia sinuata & 1 & 0 & 0 & 0 \\
\hline \multicolumn{5}{|l|}{ Blattisociidae } \\
\hline Lasioseius sp. & 0 & 3 & 1 & $11 *$ \\
\hline \multicolumn{5}{|l|}{ Melicharidae } \\
\hline Proctolaelaps sp. & $6 *$ & 0 & 0 & 0 \\
\hline \multicolumn{5}{|l|}{ Parasitidae } \\
\hline Parasitus sp. (deutonymph) & 0 & 0 & 1 & 0 \\
\hline Pergamasus sp. (deutonymph) & 0 & 0 & 0 & 1 \\
\hline \multicolumn{5}{|l|}{ Phytoseiidae } \\
\hline Neoseiulus cucumeris & 0 & 0 & 1 & 0 \\
\hline Typhlodromips masseei & 1 & 0 & $3 *$ & 0 \\
\hline Proprioseiopsis okanagensis & 0 & 0 & 1 & 1 \\
\hline Total & 8 & 3 & 29 & 13 \\
\hline
\end{tabular}

$\left.{ }^{*}\right)$ Predominant species. 
In the 'Early season', the predominant Gamasina in T2 were Melicharidae, of which Proctolaelaps sp. was the most abundant species. In T3, the predominant family was Blattisociidae, of which Lasioseius sp. was the most abundant species. In the 'Mid-season', the predominant Gamasina in T2 were Phytoseiidae, with Typhlodromips masseei (Nesbitt) the most abundant species, whereas the predominant family in T3 was Blattisociidae, with Lasioseius sp. the most abundant species.

To summarize, in the 'Early season', the total numbers of non-two-spotted spider mite found on the marked leaflets of T2 and T3 were eight and three, of which only one mite was Phytoseiidae (in T2, T. masseei). In the 'Mid-season', the total number of non-two-spotted spider mite found on marked leaflets of T2 and T3 were 29 and 13, of which 22 on T2 plants were Anystis sp. (Anystidae); of Phytoseiidae there were five mites in T2 (one Neoseiulus cucumeris (Oudemans), three T. masseei and one Proprioseiopsis okanagensis (Chant)) and one in T3 (P. okanagensis). Despite the small numbers of edaphic Gamasina, they were seen on the plants only at night (Figure 1A-D), except for Phytoseiidae and Anystidae, seen only at daytime (Figure 1C). For two-spotted spider mite, the mean numbers observed per leaflet in the fourth week of the experiment were: 'Early season': $\mathrm{T} 1=15.4 \pm 2.3, \mathrm{~T} 2=9.2 \pm 3.8$, and T3 = 10.4 \pm 3.7 ; 'Mid-season': $\mathrm{T} 1=20.4 \pm 4.1, \mathrm{~T} 2=14.3 \pm 4.0$, and T3 $=14.5 \pm 4.4$. Significant differences were observed in the 'Early season' between T1 and T2 (Df $=2 ; Z=2.55 ; p=0.02$ ), and in the 'Mid-season' between T1 and T2 ( $\mathrm{Df}=2 ; \mathrm{Z}=2.4 ; p=0.03$ ) and T1 and T3 ( $\mathrm{Df}=2 ; \mathrm{Z}=2.3 ; p=0.03$ ) (Figure 2A,B). In addition, the number of two-spotted spider mites did not vary according to evaluation times, as expected, leading us to consider each evaluation as a replicate in the statistical analysis.
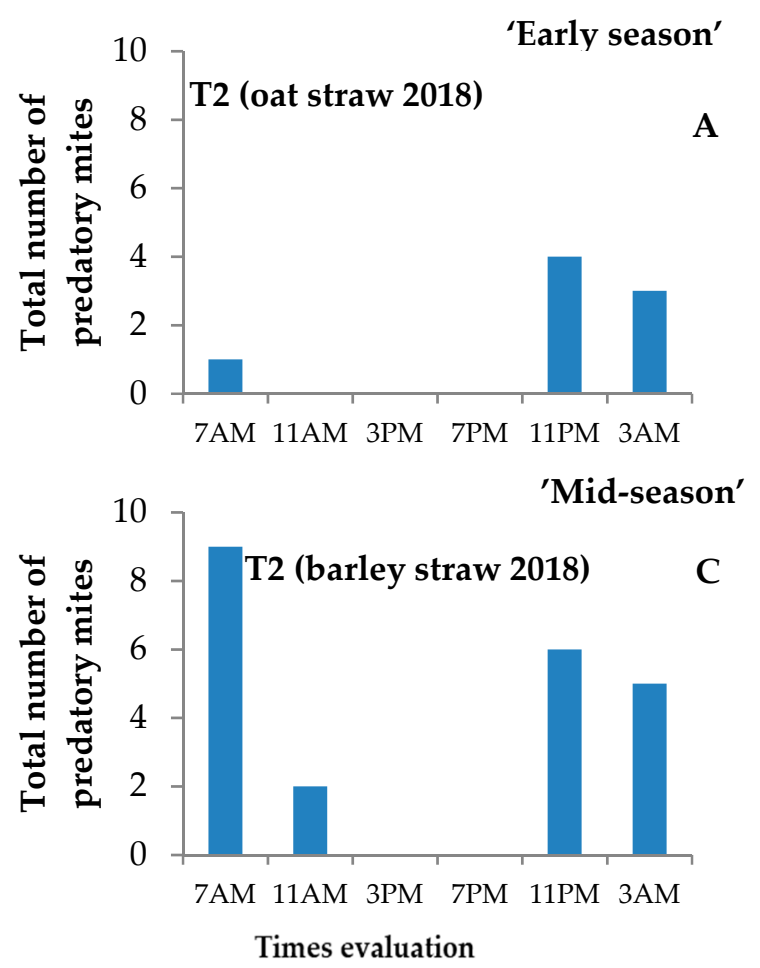

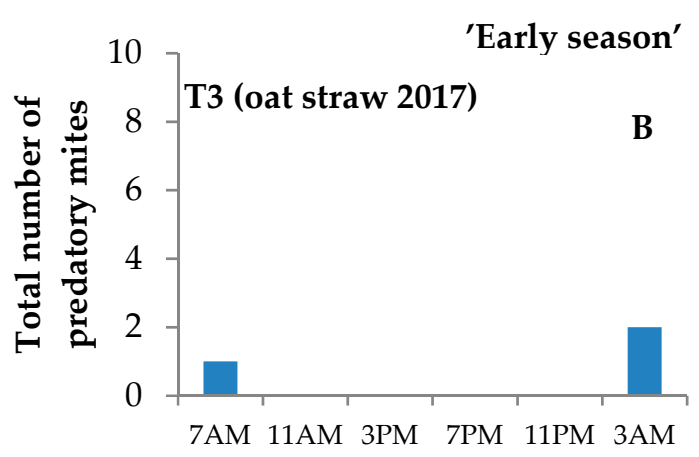

'Mid-season'

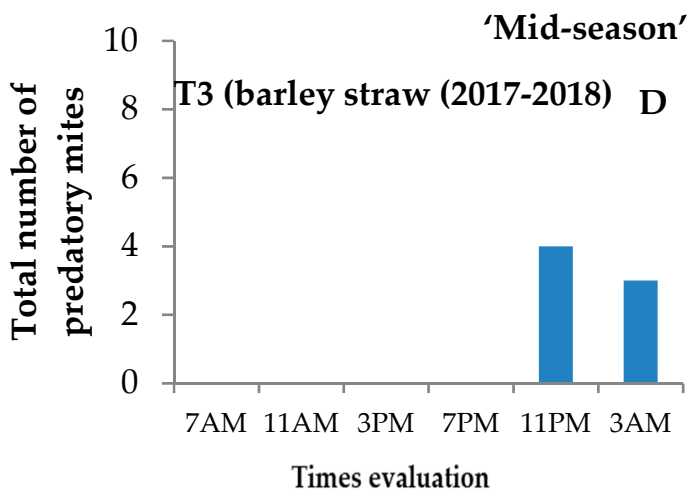

Figure 1. Weekly total numbers of Gamasina mites observed on six marked leaflets with Tetranychus urticae per plant ( $n=13$ plants per treatment). (A,B): 'Early season' experiment (T2, oat straw since 2018; T3, oat straw since 2017); (C,D): 'Mid-season' experiment (T2, barley straw since 2018; T3, barley straw lower half layer since 2017 and top half layer since 2018). Light was on from 6 a.m. to 9 p.m. 


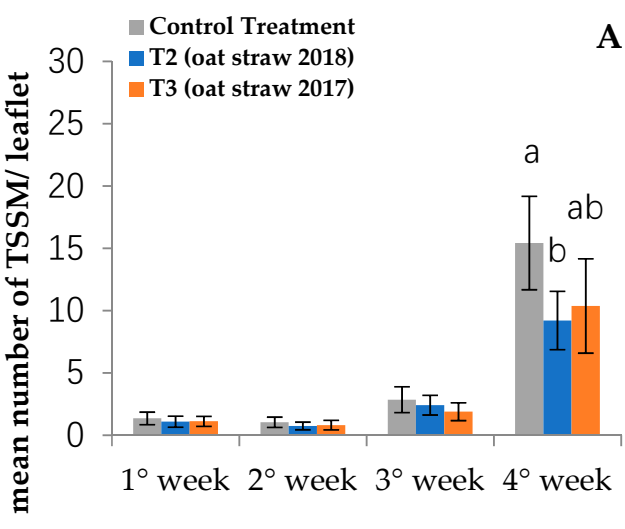

'Early season'

A

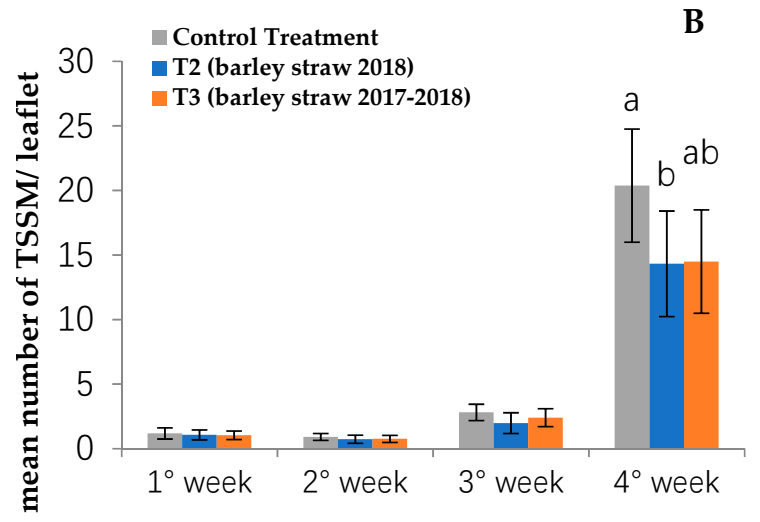

'Mid-season'

Figure 2. Weekly mean number of Tetranychus urticae observed on six marked leaflets per plant $(n=13$ plants per treatment). (A): 'Early season' experiment (T2, oat straw since 2018; T3, oat straw since 2017); (B): 'Mid-season' experiment (T2, barley straw since 2018; T3, barley straw lower half layer since 2017 and top half layer since 2018. Light was on from 6 a.m. to 9 p.m.

\subsection{Mites Extracted from Whole Plants at the End of Experiments}

No Gamasina were found on T1 plants. Considering T2 and T3 together and the two evaluation times, the number of Gamasina found in the 'Early season' (107 mites) was higher than in the 'Mid-season' (76 mites) (Table 4), coinciding with the higher number of mites in the straw at the end in the 'Early season'. The largest number of Gamasina was found on plants of T2 in both experiments. In addition, considering T2 and T3 together, Gamasina were rarely found at 11 a.m. (total of five mites), with a much larger number found at 11 p.m. (total of 102 mites); this resulted in significantly higher density of Gamasina at 11 p.m. than at 11 a.m. in both treatments and in both experiments (Table 4).

In the 'Early season', at 11 a.m. no Gamasina were found on T2 or T3 plants, in contrast to the considerable number found at 11 p.m. (Table 5). The average number of Gamasina per plant was significantly different between night and day (between 11 a.m. and 11 p.m. in T2: Df $=1 ; \mathrm{F}=73.4$; $p<0.001$; between 11 a.m. and 11 p.m. in T3: $\mathrm{Df}=1 ; \mathrm{F}=33.3 ; p<0.001)$. In the 'Mid-season', the number of Gamasina on T2 plants at 11 p.m. was higher than at 11 a.m. ( $\mathrm{Df}=1, \mathrm{~F}=10.6, p<0.01$ ), whilst in $\mathrm{T} 3$ there was no statistical difference between 11 a.m. and 11 p.m. $(\mathrm{Df}=1, \mathrm{~F}=2.1, p=0.15)$.

As to the faunistic composition, in the 'Early season' at 11 p.m., the predominant families were Melicharidae, in T2, with Proctolaelaps sp. as the most abundant species, only $18.2 \%$ of which were located at the base of the plant or on the young leaflets. In T3, the predominant family was Parasitidae, with Parasitus consanguineus Oudemans \& Voigts as the most abundant species; about $87.5 \%$ of these were found at the base of the plants. In the 'Mid-season', the predominant family in T2 was Blattisociidae, with Lasioseius sp. as the most abundant species. In T3, Gamasina always occurred at very low numbers. These results were similar to those of the evaluation of mites on leaflets only, that is, in both experiments, the largest number of predatory mites occurred in T2, both in the evaluations of only leaflets and on the whole plant.

The mean number of two-spotted spider mite per plant on leaves in T1, T2, and T3 were $176.3 \pm 10.2,143.6 \pm 14.3$, and $137.5 \pm 11.2$, respectively, in the 'Early season', and $223.8 \pm 2.5$, $138.4 \pm 18.1$, and $94.4 \pm 18.5$, respectively, in the 'Mid-season' experiment. Significant differences were observed in the 'Early season' between T1 and T3 ( $\mathrm{Df}=2 ; \mathrm{Z}=-2.2 ; p=0.0$ ) and in the 'Mid-season' between T1 and T2 (Df $=2 ; \mathrm{Z}=-3.2 ; p=0.003)$ and T1 and T3 (Df $=2 ; \mathrm{Z}=-5.1 ; p<0.001)$. Infection of the two-spotted spider mite by the fungus $N$. floridana was not observed. 
Table 4. Total number of mites (except Tetranychus urticae) of different groups extracted with $70 \%$ alcohol from whole strawberry plants. 'Early season' experiment (oat straw: T2, since 2018; T3, since 2017); 'Mid-season' experiment (barley straw: T2, since 2018; T3, lower half layer since 2017 and top half layer since 2018).

\begin{tabular}{|c|c|c|c|c|c|c|c|c|}
\hline \multirow{3}{*}{$\begin{array}{l}\text { Treatments } \\
\text { Experiments } \\
\text { Taxa/Time }\end{array}$} & \multicolumn{4}{|c|}{ T2 } & \multicolumn{4}{|c|}{ T3 } \\
\hline & \multicolumn{2}{|c|}{ 'Early Season' } & \multicolumn{2}{|c|}{ 'Mid-Season' } & \multicolumn{2}{|c|}{ 'Early Season' } & \multicolumn{2}{|c|}{ 'Mid-Season' } \\
\hline & 11 a.m. & 11 p.m. & 11 a.m. & 11 p.m. & 11 a.m. & 11 p.m. & 11 a.m. & 11 p.m. \\
\hline \multicolumn{9}{|l|}{ Trombidiformes, Prostigmata } \\
\hline \multicolumn{9}{|l|}{ Anystidae } \\
\hline Anystis sp. & 0 & 0 & 11 & 0 & 0 & 0 & 0 & 0 \\
\hline \multicolumn{9}{|c|}{ Sarcoptiformes, Oribatida, Astigmatina } \\
\hline \multicolumn{9}{|c|}{ Acaridae } \\
\hline Tyrophagus putrescentiae & 0 & 14 & 0 & 11 & 0 & 16 & 0 & 24 \\
\hline \multicolumn{9}{|c|}{ Parasitiformes, Mesostigmata, Gamasina } \\
\hline \multicolumn{9}{|c|}{ Blattisociidae } \\
\hline Lasioseius sp. & 0 & 5 & 0 & $11 *$ & 0 & 2 & 0 & 0 \\
\hline Lasioseius sp. immature & 0 & 1 & 0 & 0 & 0 & 0 & 0 & 0 \\
\hline \multicolumn{9}{|l|}{ Eviphididae } \\
\hline Alliphis halleri & 0 & 11 & 0 & 0 & 0 & 0 & 0 & 1 \\
\hline \multicolumn{9}{|l|}{ Melicharidae } \\
\hline Proctolaelaps sp. & 0 & $33 *$ & 0 & 0 & 0 & 0 & 0 & 0 \\
\hline \multicolumn{9}{|l|}{ Parasitidae } \\
\hline Amblygamasus sp. & 0 & 0 & 0 & 1 & 0 & 0 & 0 & 0 \\
\hline Amblygamasus (deutonymph) & 0 & 0 & 0 & 1 & 0 & 0 & 0 & 0 \\
\hline Pergamasus sp. (deutonymph) & 0 & 0 & 0 & 0 & 0 & 4 & 1 & 0 \\
\hline Porrhostaspis lunulata & 0 & 0 & 2 & 1 & 0 & 0 & 0 & 0 \\
\hline Parasitus consanguineus & 0 & 0 & 0 & 0 & 0 & $16^{*}$ & 0 & 0 \\
\hline Pergamasus longicornis & 0 & 0 & 0 & 0 & 0 & 1 & 0 & 4 \\
\hline Pergamasus septentrionalis & 0 & 0 & 0 & 0 & 0 & 0 & 0 & 1 \\
\hline Immature & 0 & 2 & 1 & 0 & 0 & 0 & 0 & 0 \\
\hline \multicolumn{9}{|l|}{ Phytoseiidae } \\
\hline Neoseiulus cucumeris & 0 & 1 & 0 & 2 & 0 & 0 & 0 & 0 \\
\hline Proprioseiopsis okanagensis & 0 & 0 & 1 & 1 & 0 & 0 & 0 & 0 \\
\hline Typhlodromips masseei & 0 & 0 & 0 & 1 & 0 & 1 & 0 & 0 \\
\hline \multicolumn{9}{|l|}{ Rhodacaridae } \\
\hline Rhodacarellus sp. (immature) & 0 & 0 & 0 & 1 & 0 & 0 & 0 & 0 \\
\hline Total & 0 & 67 & 15 & 30 & 0 & 40 & 1 & 30 \\
\hline
\end{tabular}

Table 5. Mean number $( \pm$ SE) of Gamasina mites per plant at 11 a.m. and 11 p.m. $(n=6$ plants $)$ with straw mulching: 'Early season' (oat straw: T2, since 2018; T3, since 2017); 'Mid-season' (barley straw: T2, since 2018; T3, lower layer since 2017 and top layer since 2018).

\begin{tabular}{lcccc}
\hline Treatments & \multicolumn{2}{c}{ T2 } & \multicolumn{2}{c}{ T3 } \\
\hline Experiments/Time & $\mathbf{1 1}$ a.m. & $\mathbf{1 1}$ p.m. & $\mathbf{1 1}$ a.m. & 11 p.m. \\
\hline 'Early season' experiment & $0.0 \pm 0.0 \mathrm{a}$ & $4.1 \pm 0.5 \mathrm{~b}$ & $0.0 \pm 0.0 \mathrm{a}$ & $1.8 \pm 0.3 \mathrm{~b}$ \\
'Mid-season' experiment & $0.3 \pm 0.1 \mathrm{a}$ & $1.5 \pm 0.4 \mathrm{~b}$ & $0.2 \pm 0.1 \mathrm{a}$ & $0.5 \pm 0.2 \mathrm{a}$ \\
\hline
\end{tabular}

In each row, different lower-case letters indicate significant statistical difference between sampling at 11 a.m. and at 11 p.m. within each treatment (Means contrasted by F test, generalized linear model of the quasi-Poisson type in R).

\section{Discussion}

Our study shows that Gamasina are present in cereal straw used as mulch in strawberry production. Both experiments confirmed our hypothesis that straw maintained longer in the field has the highest numbers and diversity of Gamasina, suggesting that organic mulch could serve as a reservoir for those organisms.

This is in accordance with the findings of Esteca et al. [20] for coffee husk maintained on the floor of a forest patch and then used as mulch in a Brazilian strawberry field. It should be expected, however, that there should be a limit to this effect over time, beyond which abundance and diversity would be reduced, due to the natural process of decomposition of the organic matter and changes in ecological conditions described by some authors [33-35]. 
The results also show that typically edaphic predators (except Anystidae and Phytoseiidae) move from cereal straw onto strawberry plants at night. This is in accordance with the findings of Britto et al. [27], who collected gerbera (Gerbera sp.) (Asteraceae) leaves from a commercial plantation Brazil. Further, it is in accordance with Esteca et al. [20] who found that the Gamasina P. pygmaeus (Melicharidae) and B. dentriticus (Blattisociidae) were present on strawberry leaflets mainly at night, indicating their possible daily migration from the edaphic environment to strawberry plants. Our results also show a lower prevalence of two-spotted spider mite in pots with straw than without, suggesting that the Gamasina moving from the straw to the plant at night might have preyed on two-spotted spider mite. However, other factors associated with the presence of straw should not be ruled out, and this would be an aspect for complementary investigation.

\subsection{Mites from the Straw, Underlying Soil, and Commercial Potting Substrate}

Although in this study our main interest centered on the Gamasina and the two-spotted spider mite, mites of other groups were also found in the straw. The diversity of mites found in the soil taken from the field was apparently low, with the occurrence of representatives of about 3-5 families (non-Astigmatina Oribatida were not identified to family) in each field. However, at least 13-14 families (also without taking into account families of non-Astigmatina Oribatida) were represented in the straw used in the experiments. Among the mites collected in this study, some Prostigmata (especially the Tydeidae) and some Astigmatina (especially Acaridae) have been considered important as alternative prey for several predatory mites. Some species of Astigmatina are extensively used as factitious food in the mass production of Gamasina for use as biological control agents [36]. In the present study, acarids were quite numerous in both experiments, and might have served as prey for some Gamasina. In fact, the acarid T. putrescentiae entered strawberry plants at night, in both the mulch treatments of both experiments. These were not present on plants at daytime. The presence of these mites on plants could somehow be related to the concurrent presence of the Gamasina on plants.

There is a large amount of information about the groups of mites effectively or potentially useful for biological pest control [15]. In a study conducted by Castilho et al. [5] in Norwegian strawberry fields, three species of some of the same genera as reported in our study (Porrhostaspis (Parasitidae), Proprioseiopsis (Phytoseiidae), and Lasioseius (Blattisociidae)) were collected. Among the Gamasina collected, some are members of the Phytoseiidae, a family that contains several species extensively used for biological pest control [37]. Of the four phytoseiid species found in this study, N. cucumeris has been widely commercialized for the control of the two-spotted spider mite and thrips on plants in different countries, including Norway [38]. Of the other families collected, Parasitidae is also commonly found in studies conducted worldwide, but these have not been reported as plant mites. Instead, they are soil inhabitants that feed mostly on nematodes and immature flies [39-41]. Based on the evaluation of the mites present in both types of straw, it was expected that parasitid species could be some of the predominant mites on strawberry leaves. This was not the case, most certainly because, despite their dominance in the straw, strawberry leaves and associated organisms in the climatic room were not attractive to them. Parasitid species have been evaluated for the biological control of pest organisms, especially of thrips [41], and the parasitid P. longicornis was previously reported from several coastal habitats in Norway [42]. Mites of the same genus have also been found in soil of strawberry fields in Brazil [20].

Ascidae, Blattisociidae, and Melicharidae, Gamasina groups found in this study, have not been used commercially, but some studies have demonstrated their potential as biological control agents, especially in humid habitats [43]. Mites of these groups seem to be generalists, being able to feed on fungi and to prey on mites and small insects. Melicharids have been reported to feed on immatures of small fruit flies (members of the Drosophilidae family), an insect group that contains an important direct strawberry pest, present in several countries, including Norway [43]. The melicharid P. pygmaeus was found in Norway in a coniferous forest [44]. In a study carried out in Brazil, this mite was found 
in large numbers in coffee husk used as mulching in strawberry fields [20]. It has been reported to consume eggs of Drosophila spp. [43] and two-spotted spider mite [45].

The Rhodacaridae have been inadequately studied for use as a biocontrol agent, but an important characteristic of species of this group is their small size, facilitating their movement below the soil surface, where they can encounter plant feeding nematodes, which they have been shown to be able to consume [40]. Eviphidids and veigaiids have also received little attention as biocontrol agents. This is apparently the first report of the eviphidid A. halleri in Norway, but this mite has already been reported in neighboring Sweden [46]. Eviphidids are commonly found in agricultural soils, phoretically on insects, especially beetles, and in manure. Interest in this group stems in part from the fact that it contains species known to prey on plant-feeding nematodes [47]. The veigaiid V. nemorensis was previously reported in Norway, both in natural and modified environments [40]. Mites of this family are common in litter, feeding on other mites and small arthropods [48].

Some of the Prostigmata collected (especially Anystidae and Cunaxidae) are also known to be predators [36]. However, they have not been developed as commercially available biocontrol agents, probably because of the difficulties in mass production.

\subsection{Mites on Strawberry Plants}

What would cause mites to move from the ground surface to plants and vice-versa? In general, the movement could occur to escape stress factors of relatively long duration. An example is excess humidity, as evidenced by the movement of Oribatida from the soil to the trees in the Amazon forest, in the rainy season of each year [49]. Other stressors may lead to the occurrence of diapause, common in phytoseiids [37,50] and tetranychids [51], stimulating the mites to move away from their usual habitat while active.

However, factors of shorter duration might also be involved and related to daily movements of mites. They could move from plants to soil during the day to escape low levels of relative humidity. Conversely, they could move back to plants at night, among other reasons, to search for food and/or places with lower competition (due to the diversity and abundance of predators, this is usually lower on plants than in the soil) and less intra-guild predation. Such movement could promote the biological control of potential pest organisms on plants.

The diversity of mites on plants was quite high in this study compared to another study conducted in Norwegian strawberry fields [5]. About eight species were found when a few single leaflets were visually examined; this number was roughly doubled when all plants were washed in alcohol, therefore, changing the plant volume and the method. However, with few exceptions, the number of specimens was low. Regarding the most common groups on plants (the blattisociid Lasioseius sp., the melicharid Proctolaelaps sp., and the anystids), the same response was observed in the evaluation of mites on leaflets and on the whole plants. However, there was a difference concerning the parasitid P. consanguineus, which was not collected from leaflets, but in relatively large numbers on whole plants. The main reason for this difference is probably the occurrence of this species in the crown of the strawberry plants, and not on leaves. In the present study, anystids were only found in the 'Mid-season' experiment, in which they were observed in significant numbers on plants with young cereal straw, and only at daytime. The anystid Anystis agilis (Banks) has been cited as a predator of the mites Panonychus citri (McGregor), two-spotted spider mite, and the thrips Scirtothrips citri Moultan [52]. These pests are found in the aerial part of the plants, although $S$. citri is also found in the soil or litter in the non-feeding resting stages. The anystids found in this study could have helped to reduce the number of two-spotted spider mite on the strawberry leaflets on plants with young cereal straw of the 'Mid-season' experiment, but reports of predation of anystids on two-spotted spider mite are not satisfactory in the literature, and this should be further investigated.

The phytoseiids N. cucumeris, P. okanagensis, and T. masseei have previously been collected on strawberry in Norway $[5,53,54]$, but this is the first time $N$. cucumeris has been found in a Norwegian strawberry crop where it has never been released as a biocontrol agent of mites (including two-spotted 
spider mite [38]) or thrips. Only one specimen of this species has ever been recorded as naturally occurring in Norway (on Corylus avellana L. [55]). Thus, N. cucumeris is either naturally occurring in the area or it has followed the plant material. Regarding P. okanagensis, this species is definitely native in Norway. According to Meshkov [56], it does not feed on two-spotted spider mite to a significant extent.

Other studies have also reported the difference between the mite fauna on the leaves of certain plants in daytime and nighttime observations [20,25,57,58]. The movement of certain Gamasina biological control agents onto strawberry plants at night and the lower two-spotted spider mite numbers in straw treatments indicates that edaphic Gamasina prey on two-spotted spider mite and suggest that the use of straw with Gamasina may be an interesting conservational biocontrol strategy.

However, not all groups of Gamasina may be inclined to climb plants at night. The results of this study suggested that while some Gamasina apparently venture to visit the regions of more extensive surface in the plant, that is, the leaflets (Blattisociidae, Melicharidae), others visit only the parts closest to the soil, that is, the region of the crown of the plants, as observed for the parasitid P. consanguineus. The results also indicate that some Gamasina, such as Eviphididae, even when relatively abundant in the substrate, do not appear to climb the plants often. This suggests that their role as biological control agents on strawberry plants may not be significant.

\section{Conclusions}

Our study suggests that the use of cereal mulching by strawberry producers in Norway allows the maintenance of a larger number of predatory mites in the environment than would be possible without mulching. Further, it suggests that cereal straw maintained in the field for a longer time (2 years) hosts more predatory mites than cereal straw maintained for a shorter period (1 year). Organic soil mulch facilitates the maintenance of predators in the field, as extensively reported in the literature [10-15]. The difference between the abundance of Gamasina mites in the soil and in the straw was expected, as these mites are not only predators (usually unspecific), but also feed on other organisms found in the mulching, including fungi $[44,59,60]$.

Although the main finding of the present study was the confirmation of nocturnal movement of the Gamasina from straw mulch to strawberry plants, the opposite behavior was also observed. Unlike Gamasina, anystids were observed on plants only during the day, suggesting an inverse movement of the Gamasina, perhaps helping in the reduction of intra-guild predation.

The results of this study may be useful in subsequent research to evaluate the performance of strawberry crops that incorporate the use of cereal straw used in previous years as mulching, favoring the maintenance of edaphic predatory mites in the field. In subsequent research, it seems recommendable to evaluate the potential predation and oviposition of Gamasina mites found in the aerial part of the strawberry plants when offered common strawberry pests. Moreover, in future studies, when sampling predatory mites on strawberry plants, the time of the day should be taken into account, and sampling should also be done at night.

Results could have been different, had we inoculated the plants with other organisms, onto which the edaphic mite might feed. Further, it might be worthwhile to conduct a similar study under field conditions, where environmental factors alter more slowly and in concert, which was not possible to incorporate in the present study.

Author Contributions: Conceptualization, F.d.C.N.E., N.T., I.K. and G.J.d.M.; Data curation, F.d.C.N.E., N.T., I.K., J.C.S., I.D.J. and G.J.d.M.; Formal analysis, F.d.C.N.E., J.C.S. and G.J.d.M.; Funding acquisition, N.T., I.K., I.D.J. and G.J.d.M.; Investigation, F.d.C.N.E., N.T., I.K. and G.J.d.M.; Methodology, F.d.C.N.E., N.T., I.K. and G.J.d.M.; Project administration, F.d.C.N.E., N.T., I.K. and G.J.d.M.; Resources, N.T., I.K., I.D.J. and G.J.d.M.; Supervision, N.T., I.K. and G.J.d.M.; Writing-original draft, F.d.C.N.E., N.T., I.K., I.D.J. and G.J.d.M. All authors have read and agreed to the published version of the manuscript.

Funding: This research was funded by CNPq (Conselho Nacional de Desenvolvimento Científico e Tecnológico) and The Research Council of Norway through the SMARTCROP project (Project Number 244526).

Acknowledgments: We are grateful to Marta Bosque Fajardo and Marit Helgheim at NIBIO for their practical assistance in conducting this work; to the José Bruno Malaquias at ESALQ-USP for help with statistics, and to 
Marina Ferraz de Barbosa Camargo at ESALQ-USP for help in identifying Astigmatina mites. Last but not least we thank the Saxebøl family for answering lots of questions and letting us sample straw mulching from their strawberry field.

Conflicts of Interest: The authors declare no conflict of interest.

\section{References}

1. Chakraborty, D.; Nagarajan, S.; Aggarwal, P.; Gupta, V.K.; Tomar, R.K.; Garg, R.N.; Sahoo, R.N.; Sarkar, A.; Chopra, U.K.; Sarma, K.S.S.; et al. Effect of mulching on soil and plant water status: And the growth and yield of wheat (Triticum aestivum L.) in a semi-arid environment. Agric. Water Manag. 2008, 95, 1323-1334. [CrossRef]

2. Haslestad, J.; (Norsk Landbruksrådgivning, Ribadu, Hedmark, Norway). Personal communication, 2020.

3. Vi Spiser Mer Utenlandske Enn Norske Jordbær. Available online: https://www.ssb.no/jord-skogjakt-og-fiskeri/artikler-og-publikasjoner/vi-spiser-mer-utenlandske-enn-norske-jordbaer (accessed on 22 January 2020).

4. Statistics Norway. Available online: https://www.ssb.no/en (accessed on 24 May 2020).

5. Castilho, R.C.; Duarte, V.S.; Moraes, G.J.; Westrum, K.; Trandem, N.; Rocha, L.C.D.; Delalibera, I., Jr.; Klingen, I. Two-spotted spider mite and its natural enemies on strawberry grown as protected and unprotected crops in Norway and Brazil. Exp. Appl. Acarol. 2015, 66, 509-528. [CrossRef] [PubMed]

6. Trandem, N. Greenhouse production of strawberries and blackberries in Norway-arthropod pests and biological control. In Proceedings of the IOBC/ WPRS Working Group "Integrated Plant Protection in Orchards" Subgroup "Soft Fruits", Dundee, Scotland, 18-21 September 2001; Gordon, S.C., Cross, J.V., Eds.; Scottish Crop Research Institute: Dundee, Scotland, 2003; Volume 26, pp. 45-50.

7. Klingen, I.; Westrum, K.; Meyling, N.V. Effect of Norwegian entomopathogenic fungal isolates against Otiorhynchus sulcatus larvae at low temperatures and persistence in strawberry rhizospheres. Biol. Control. 2015, 81, 1-7. [CrossRef]

8. Aasen, S.S.; Trandem, N. Strawberry blossom weevil Anthonomus rubi Herbst (Col.: Curculionidae): Relationships between bud damage, weevil density, insecticide use, and yield. J. Pest. Sci. 2006, 79, 169-174. [CrossRef]

9. Kader, M.A.; Senge, M.; Mojid, M.A.; Ito, K. Recent advances in mulching materials and methods for modifying soil environment. Soil Till. Res. 2017, 168, 155-166. [CrossRef]

10. Johnson, J.M.; Hough-Goldstein, J.A.; Vangessel, M.J. Effects of straw mulch on pest insects, predators, and weeds in watermelons and potatoes. Environ. Entomol. 2004, 33, 1632-1643. [CrossRef]

11. Larentzaki, E.; Plate, J.; Nault, B.; Shelton, A. Impact of straw mulch on populations of onion thrips (Thysanoptera: Thripidae) in onion. J. Econ. Entomol. 2008, 101, 1317-1324. [CrossRef]

12. Hoddle, M.S.; Morse, J.G.; Phillips, P.A.; Faber, B.A.; Jetter, K.M. Avocado thrips: A new challenge for growers. Cali Agric. 2002, 56, 103-107. [CrossRef]

13. Jensen, L.; Simko, B.; Shock, C.; Saunders, L. Alternative Methods for Controlling Onion Thrips (Thrips tabaci) in Spanish Onions; Malheur Experiment Station Annual Report 2001; Oregon State University Agricultural Experiment Station: Ontario, OR, Canada, 2002; Volume 1038, pp. 104-111.

14. Jamieson, L.E.; Stevens, P.S. The effect of mulching on adult emergence of Kelly's citrus thrips (Pezothrips kellyanus). N. Z. Plant. Prot. 2006, 59, 42-46.

15. Sánchez-Moreno, S.; Ferris, H. Suppressive service of the soil food web: Effects of environmental management. Agric. Ecosyst. Environ. 2007, 119, 75-87. [CrossRef]

16. Carrillo, D.; Moraes, G.J.; Peña, J.E. Prospects for Biological Control. of Plant. Feeding Mites and Other Harmful Organisms; Springer International Publishing: Cham, Switzerland, 2015; p. 337.

17. Walter, D.E.; Proctor, H.C. Mites: Ecology, Evolution and Behaviour Life at a Microscale, 2nd ed.; Springer Science and Business Media: Dordrecht, The Netherlands, 2013; p. 509.

18. Bottinelli, N.; Jouquet, P.; Capowiez, Y.; Podwojewski, P.; Grimaldi, M.; Peng, X. Why is the influence of soil macrofauna on soil structure only considered by soil ecologists? Soil Till. Res. 2015, 146, 118-124. [CrossRef]

19. Raven, P.H.; Evert, R.F.; Eichorn, S.E. Biologia Vegetal; Guanabara-Koogan: Rio de Janeiro, Brasil, 2001 ; p. 906. 
20. Esteca, F.C.N.; Rodrigues, L.R.; Moraes, G.J.; Júnior, I.D.; Klingen, I. Mulching with coffee husk and pulp in strawberry affects edaphic predatory mite and spider mite densities. Exp. Appl. Acarol. 2018, 76, 161-183. [CrossRef] [PubMed]

21. Karg, W. Syno“kologische Untersuchungen von Bodenmilben aus forstwirtschaftlich und landwirtschaftlich genutzten Böden. Pedobiologia 1967, 7, 198-214.

22. van de Bund, C.F. Gamasides as predators of phytophagous nematodes. In Problems of Acarology, Symposium; Bozek, J., Suski, Z.W., Jakubowska, J., Eds.; Publisher: Polska Akademia Nauk, Polska, 1970; p. 280.

23. Walter, D.E.; Behan-Pelletier, V. Mites in forest canopies: Filling the size distribution shortfall? Annu. Rev. Entomol. 1999, 44, 1-19. [CrossRef] [PubMed]

24. Onzo, A.; Hanna, R.; Zannou, I.; Sabelis, M.W.; Yaninek, J.S. Dynamics of refuge use: Diurnal, vertical migration by predatory and herbivorous mites within cassava plants. Oikos 2003, 101, 59-69. [CrossRef]

25. Parecis-Silva, P.V.; Nuvoloni, F.M.; Feres, R.J. Day vs. night: The importance of the circadian cycle over metacommunities and predator-prey densities. Int. J. Acarol. 2016, 42, 141-148. [CrossRef]

26. Fagan, L.L.; Didham, R.K.; Winchester, N.N.; Behan-Pelletier, V.; Clayton, M.; Lindquist, E.E.; Ring, R.A. An experimental assessment of biodiversity and species turnover in terrestrial versus canopy leaf litter. Oecologia 2006, 147, 335-347. [CrossRef]

27. Britto, E.P.J.; Gago, E.; Moraes, G.J. How promising is Lasioseius floridensis as a control agent of Polyphagotarsonemus latus? Exp. Appl. Acarol. 2012, 56, 221-231. [CrossRef]

28. Meier, U.; Graf, H.; Hess, M.; Kennel, W.; Klose, R.; Mappes, D.; Seipp, D.; Stauss, R.; Streif, J.; van den Boom, T. Phänologische Entwick-lungsstadien des Kernobstes (Malusdomestica Borkh. Und Pyrus communis L.), des Steinobstes (Prunus-Arten), der Johannisbeere (Ribes-Arten) und der Erdbeere (Fragaria x ananassa Duch.). Nachrichtenbl. Deut. Pflanzenschutzd 1994, 46, 141-153.

29. Oliveira, A.R.; Moraes, G.J.; Demétrio, C.G.E.; Nardo, E.A.E. Efeito do vírus de poliedrose nuclear de Anticarsia gemmatalis sobre Oribatida edáficos (Arachnida: Acari) em um campo de soja. Embrapa Meio Ambiente 2001, 13, 5-31.

30. Krantz, G.W.; Walter, D.E. A Manual of Acarology, 3rd ed.; Texas Tech University Press: Lubbock, TX, USA, 2009; p. 411.

31. R Development Core Team. R: A Language and Environment for Statistical Computing, v.3.0.1; R foundation for Statistical Computing: Vienna, Austria, 2013.

32. Pinzón, J.; Spence, J.R. Bark-dwelling spider assemblages (Araneae) in the boreal forest: Dominance, diversity, composition and life-histories. J. Insect. Conserv. 2010, 14, 439-458. [CrossRef]

33. Sjursen, H.; Michelsen, A.; Jonasson, S. Effects of long term soil warming and fertilization on microarthropod abundances in three sub-artic ecosystems. Appl. Soil Ecol. 2005, 30, 148-161. [CrossRef]

34. Blankinship, J.C.; Niklaus, P.A.; Hungate, B.A. A meta-analysis of responses of soil biota to global change. Oecologia 2011, 165, 553-565. [CrossRef]

35. Bedano, J.C.; Ruf, A. Sensitivity of different taxonomic levels of soil Gamasina to land use and anthropogenic disturbances. Agric. Forest Entomol. 2010, 12, 203-212. [CrossRef]

36. Hernandes, F.A.; Castro, T.M.M.; Venancio, R. Prostigmata (Acari: Trombidiformes) as biological control agents. In Prospects for Biological Control of Plant Feeding Mites and Other Harmful Organisms; Carillo, D., Moraes, G.J., Peña, J.E., Eds.; Springer International Publishing: Cham, Switzerland, 2015; pp. 151-184.

37. McMurtry, J.A.; Sourassou, N.F.; Demite, P.R. The Phytoseiidae (Acari: Mesostigmata) as biological control agents. In Prospects for Biological Control of Plant Feeding Mites and Other Harmful Organisms; Carillo, D., Moraes, G.J., Peña, J.E., Eds.; Springer International Publishing: Cham, Switzerland, 2015; pp. 133-149.

38. Knapp, M.; van Houten, Y.; van Baal, E.; Groot, T. Use of predatory mites in commercial biocontrol: Current status and future prospects. Acarologia 2018, 58, 72-82.

39. Szlendak, E.; Lewandowski, M. Development and reproductive capacity of the predatory mite Parasitus consanguineus (Acari: Parasitidae) reared on the larval stages of Megaselia halterata and Lycoriella ingenua. Exp. Appl. Acarol. 2009, 47, 285-292. [CrossRef]

40. Castilho, R.C.; Venancio, R.; Narita, J.P.Z. Mesostigmata as biological control agents, with emphasis on Rhodacaroidea and Parasitoidea. In Prospects for Biological Control of Plant Feeding Mites and Other Harmful Organisms; Carillo, D., Moraes, G.J., Peña, J.E., Eds.; Springer International Publishing: Cham, Switzerland, 2015; pp. 1-31. 
41. Rueda-Ramírez, D.; Rios-Malaver, D.; Varela-Ramírez, A.; Moraes, G.J. Biology and predation capacity of Parasitus bituberosus (Acari: Mesostigmata: Parasitidae) on Frankliniella occidentalis (Thysanoptera: Thripidae), and free-living nematodes as its complementary prey. Pest. Manag. Sci. 2019, 75, 1819-1830. [CrossRef]

42. Bolger, T.; Devlin, M.; Seniczak, A. First records of ten species of Mesostigmata (Acari, Mesostigmata) added to the published Norwegian species list. Nor. J. Entomol. 2018, 65, 94-100.

43. Moraes, G.J.; Venancio, R.; dos Santos, V.L.V.; Paschoal, A.D. Potential of Ascidae, Blattisociidae and Melicharidae (Acari: Mesostigmata) as biological control agents of pest organisms. In Prospects for Biological Control of Plant Feeding Mites and Other Harmful Organisms; Carillo, D., Moraes, G.J., Peña, J.E., Eds.; Springer International Publishing: Cham, Switzerland, 2015; pp. 33-75.

44. Slomian, S.; Gulvik, M.E.; Madej, G.; Austad, I. Gamasina and Microgyniina (Acari, Gamasida) from soil and tree hollows at two traditional farms in Sogn og Fjordane, Norway. Norw. J. Entomol. 2005, 52, 39-48.

45. Lindquist, E.E.; Krantz, G.W.; Walter, D.E. Order Mesostigmata. In A Manual of Acarology, 3rd ed.; Krantz, G.W., Walter, D.E., Eds.; Texas Tech University Press: Lubbock, TX, USA, 2009; pp. 124-232.

46. Halliday, R.B. Alliphis siculus (Oudemans 1905) is not a synonym of Alliphis halleri (G. \& R. Canestrini 1881) (Acari: Eviphididae). Syst. Appl. Acarol. 2008, 13, 51-64.

47. Karg, W.; Grosse, E. Raubmilben als Antagonisten von Nematoden. Nachr. Pflanzenschutz DDR 1983, 37, 208-212.

48. Mathys, G.; Tencalla, Y. Note préliminaire sur la biologie et la valeur prédatice de Proctolaelaps hypudaei Oudms (Acarien: Mesostigmata: Aceosejidae). Stn. Fédérales Essais Agric. 1959, 600, 645-654.

49. Moraes, J.; Franklin, E.; Morais, J.W.; Souza, J.L.P. Species of edaphic mites (Acari: Oribatida) and effects of topography, soil properties and litter gradients on their qualitative and quantitative composition in $64 \mathrm{~km}^{2}$ of forest in Amazonia. Exp. Appl. Acarol. 2011, 55, 39-63. [CrossRef] [PubMed]

50. Overmeer, W.P.J. Diapause. Spider Mites: Their Biology, Natural Enemies and Control; Elsevier: Amsterdam, The Netherlands, 1985; Volume 2, pp. 95-102.

51. Veerman, A. Diapause. Spider Mites: Their Biology, Natural Enemies and Control; Elsevier: Amsterdam, The Netherlands, 1985; Volume 1, pp. 279-316.

52. Laing, J.E.; Knop, N.F. Potential use of predaceous mites other than Phytoseiidae for biological control of orchard pests. In Biological Control of Pests by Mites, Special Publications; Hoy, M.A., Cunningham, G.L., Knutson, L., Eds.; University of California: Berkeley, CA, USA, 1983; pp. 12-20.

53. Karg, W.; Edland, T. Neue Raubmilbenarten der Phytoseiidae Berlese, 1916. Dtsch. Entomol. Z. 1987, 34, 387-395. [CrossRef]

54. Trandem, N.; Klingen, I.; Haukeland, S.; Moraes, G.J. The occurrence of two pest mites and three groups of biocontrol agents in organic and conventional strawberry fields (abstract only). IOBC Bull. 2011, 70, 96.

55. Denmark, H.A.; Edland, T. The subfamily Amblyseiinae Muma (Acari: Phytoseiidae) in Norway. Int. J. Acarol. 2002, 28, 195-220. [CrossRef]

56. Meshkov, Y.I. Phytoseiid Mites (Parasitiformes, Phytoseiidae) on Main Berry Plantings. Ph.D. Thesis, Bolshie Vjazemi, Moscow, Russia, 1996.

57. Novotny, V.; Basset, Y.; Auga, J.; Boen, W.; Dal, C.; Drozd, P.; Kasbal, M.; Isua, B.; Kutil, R.; Manumbor, M. Predation risk for herbivorous insects on tropical vegetation: A search for enemy-free space and time. Aust. J. Ecol. 1999, 24, 477-483. [CrossRef]

58. Saigusa, M.; Oishi, K.; Ikumoto, A.; Iwasaki, H.; Terajima, M. Emergence patterns of small subtidal arthropods in relation to day/night, tidal, and surface/bottom factors: Investigations in the Boreal Sea, Japan (Akkeshi, Hokkaido). J. Oceanogr. 2000, 56, 295-310. [CrossRef]

59. Zaitsev, A.S.; Chauvat, M.; Pflug, A.; Wolters, V. Oribatid mite diversity and community dynamics in a spruce chronosequence. Soil Biol. Biochem. 2002, 34, 1919-1927. [CrossRef]

60. Walter, D.E.; Hunt, H.W.; Elliott, E.T. Guilds or functional groups? An analysis of predatory arthropods from a shortgrass steppe soil. Pedobiologia 1988, 31, 247-260.

(C) 2020 by the authors. Licensee MDPI, Basel, Switzerland. This article is an open access article distributed under the terms and conditions of the Creative Commons Attribution (CC BY) license (http://creativecommons.org/licenses/by/4.0/). 